\title{
Evaluation of the bactericidal effect of strong acid electrolysed water against Enterococcus faecalis and Porphyromonas gingivalis in primary molar root canal: An in vivo study
}

\author{
*Ashwin B Abraham ${ }^{1}$, Roopa K B ${ }^{2}$, Poornima $\mathbf{P}^{3}$, Mallikarjuna $\mathbf{K}^{2}$, Nagaveni $\mathbf{N} \mathbf{B}^{2}$, Bharath K $\mathbf{P}^{4}$
}

Sri Lanka Journal of Child Health, 2021; 50(3): 416-423

\begin{abstract}
Introduction: Strong acid electrolysed water (SAEW), a root canal irrigant, has shown promise against resistant microorganisms like Enterococcus faecalis (E. faecalis) and Porphyromonas gingivalis ( $P$. gingivalis).
\end{abstract}

Objective: To compare in vivo antimicrobial efficacy of 3\% sodium hypochlorite and SAEW against E. faecalis and $P$. gingivalis in primary teeth.

Method: Seventy primary maxillary and mandibular posterior teeth of 4-10 year old children were irrigated either with 3\% sodium hypochlorite $(n=35)$ or SAEW $(n=35)$. Paper point samples were collected at baseline, after chemo-mechanical preparation and 48 hours after irrigation during pulpectomy. Presence of E. faecalis and $P$. gingivalis in the three samples were evaluated using culture.

Results: When compared to SAEW, the antimicrobial efficacy of $3 \%$ sodium hypochlorite was not significantly different $(\mathrm{p}>0.05)$.

Conclusions: SAEW and 3\% sodium hypochlorite are equally efficient irrigants against $E$. faecalis and $P$. gingivalis in necrotic primary molar teeth.

DOI: http://doi.org/10.4038/sljch.v50i3.9689

(Key words: Porphyromonas gingivalis, Enterococcus faecalis, primary teeth, sodium hypochlorite, strong acid electrolysed water)

${ }^{1}$ Postgraduate Student, ${ }^{2}$ Professor ${ }^{3}$ Professor and Head, ${ }^{4}$ Reader, Department of Pedodontics and Preventive Dentistry, College of Dental Sciences, Davangere, Karnataka, India

*Correspondence: drashwinabraham@gmail.com

https://orcid.org/0000-0003-0096-3029

(Received on 17 July 2020: Accepted after revision on 21 August 2020)

The authors declare that there are no conflicts of interest

Personal funding was used for the project.

Open Access Article published under the Creative

Commons Attribution CC-BY (C) (i)

\section{Introduction}

Chronically infected deciduous root canals have always been a haven for anaerobic bacteria like Enterococcus faecalis (E. faecalis) and Porphyromonas gingivalis $(P \text {. gingivalis })^{1,2}$. A perfect root canal irrigant should be biocompatible, anti-bacterial, provide efficient lubrication for instrumentation and have debridement capability. Till today, we are using sodium hypochlorite $(\mathrm{NaOCl})$ as an effective irrigant, even though aware of its toxic disadvantages ${ }^{3,4}$. The food industry reaped the benefits of electrolysed water, which is safe, effective, provides disinfection on contact and is also bactericidal against E. faecalis biofilms just like $\mathrm{NaOCl}$. Strong acid electrolysed water (SAEW) has been investigated as a potential root canal irrigant in the recent past $^{3}$. From what we know, there has not been any in vivo study on the effect of acidic electrolysed water on infected primary root canal flora.

\section{Objectives}

To assess the bactericidal ability of SAEW and 3\% $\mathrm{NaOCl}$ against $E$. faecalis and $P$. gingivalis in infected deciduous molar root canals.

\section{Method}

This in vivo study was undertaken on 70 deciduous molar teeth in systemically healthy, 4 to 10 year $^{5}$ old children needing pulpectomy treatment. They were chosen randomly from the outpatient section in the Department of Paediatric and Preventive Dentistry, College of Dental Sciences, Karnataka, India.

Inclusion criteria consisted of systemically well children with periapical or furcal radiolucency ${ }^{6}$, at least two carious primary molars indicated for pulpectomy, root resorption less than one third ${ }^{2}$, sufficient tooth structure to support rubber dam ${ }^{6}$ and primary posterior teeth with pulp necrosis.

Exclusion criteria included teeth with excessive mobility, traumatic injuries, too much root resorption, unhealthy periodontium, developmental anomalies and children who consumed antibiotics within the last three months ${ }^{6}$.

Sample collection: After adequate local anaesthesia and scaling, rubber dam isolation (Figure 1) of the teeth was achieved and the tooth was wiped with $10 \%$ povidone iodine. After five minutes, isopropyl alcohol was rubbed on the tooth surface ${ }^{5}$. Slow and high speed burs were used to 
excavate the dental caries. High speed, diamond, round bur (BR-31) flushed with sterile water was used to gain access into the pulp chamber. Chamber irrigation was done with $0.9 \%$ saline and disinfection with $3 \% \mathrm{NaOCl}$.

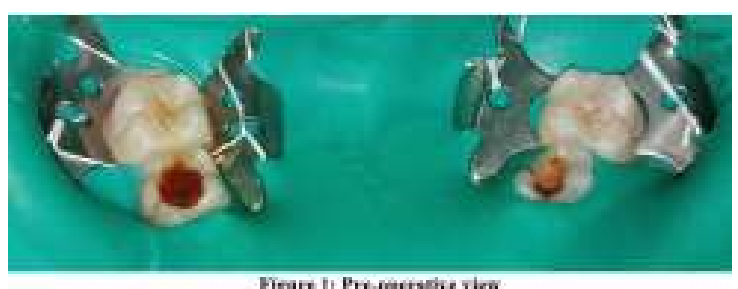

Widest canals were chosen for sample collection, distal and palatal canal in mandibular and maxillary molars respectively ${ }^{2}$. For the first microbiological sample (Sample 1), saline irrigation was followed by introduction of a number 20 Hedstroem file in a gentle filing motion, $1 \mathrm{~mm}$ short of the apex approximately after cross checking the length on diagnostic radiograph. Sterile paper points were introduced into the canals for 60 seconds (Figure 2).

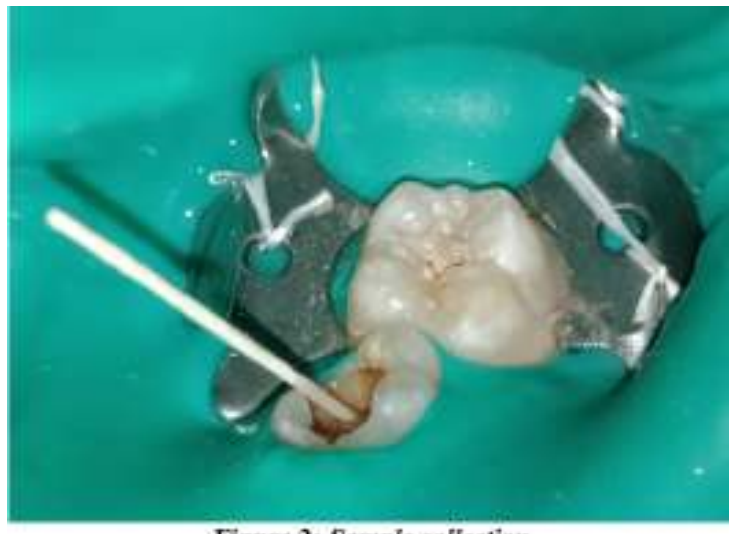

Figure 2: Sample collection

These paper points were introduced into the aseptic Eppendorf tube containing reduced transport media. Instrumentation was then executed with Hedstroem files till size 40 in an alternating back and forth rotation motion. For each group, $2 \mathrm{ml}$ of respective irrigant in a 26 -gauge sterile needle and syringe was used $^{5}$. Irrigant used for group A (35 teeth) was $3 \% \mathrm{NaOCl}$. In group $\mathrm{B}$ (35 teeth) customized SAEW was used. After instrumentation of the canals, they were irrigated with $0.9 \%$ sterile saline. The second microbiological sample (Sample 2) was obtained by leaving a sterile paper point analogous to the canal diameter for 60 seconds.
These paper points were transferred into sterile Eppendorf tubes with reduced transport media. Subsequently the opened cavity was sealed with an aseptic cotton pellet in the chamber and Glass ionomer cement (GIC) (Figure 3) ${ }^{5}$, after instrumentation, irrigation and drying. Any high points were reduced if needed.

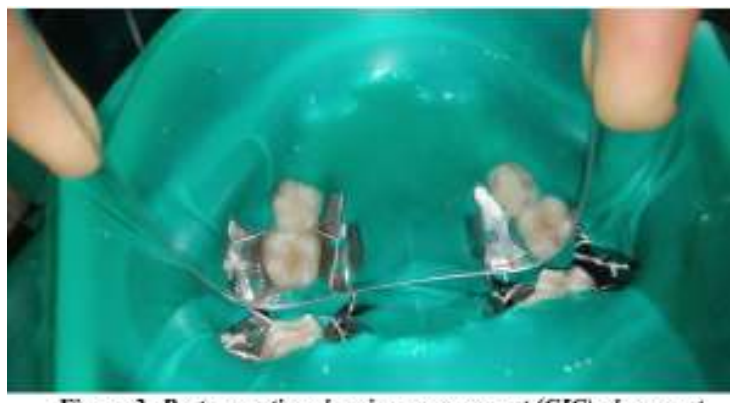

Figure 3: Post-operative glass ionomer cement (GIC) placement

To assess the antimicrobial potential of the remnant irrigant in the canal, the patients were summoned after 48 hours $^{5,6}$. The pulp chambers were exposed under rubber dam isolation and with the high speed diamond round bur (BR-31). The cotton pellet was removed from the chamber. The third sample (Sample 3) was obtained by placing a sterile paper point in the canal for 60 seconds and transferring it to the reduced transport media in the Eppendorf tube to send it to the clinical microbiology laboratory for culturing within 48 hours. This was followed by completion of the pulpectomy procedure.

Ethical issues: Ethical approval was obtained from the Institutional Ethics Committee of the College of Dental Sciences, Davangere, Karnataka, India (Ref. CODS/IEC/1810/2016-2017). Written informed consent was taken from the guardian or parent of the child before his or her inclusion in the study.

Statistical analysis: Friedman's test was used for intragroup comparison of the colony count from the pre-irrigation, post-instrumentation and post-48 hours of irrigation samples within both groups (Tables 1 and 3). Mann-Whitney $U$ test was done for intergroup analogy (Tables 2 and 4). Wilcoxon matched pairs test was done for analogy of sample values in group I (Table 3). IBM Statistical Package for the Social Sciences (SPSS) version 24 was used for statistical analysis. The statistical significance level was fixed at $5 \%(\mathrm{p}<0.05)$. 
Table 1: Comparison of E. faecalis colony count at different time intervals in each study group

\begin{tabular}{|c|c|c|c|c|c|c|c|}
\hline \multirow[t]{2}{*}{ Group } & \multirow[t]{2}{*}{ Sample } & \multirow[t]{2}{*}{ Number } & \multirow[t]{2}{*}{ Mean (SD) } & \multirow[t]{2}{*}{ Range } & \multirow{2}{*}{$\begin{array}{l}\text { Median } \\
\text { (Q1-Q3) }\end{array}$} & \multicolumn{2}{|c|}{ Friedman test } \\
\hline & & & & & & Chi square & p-value \\
\hline \multirow{3}{*}{ I } & 1 & 35 & $16.86(37.08)$ & $0-150$ & $0(0-10)$ & \multirow{3}{*}{0.75} & \multirow{3}{*}{0.69} \\
\hline & 2 & 35 & $16.57(38.57)$ & $0-150$ & $0(0-0)$ & & \\
\hline & 3 & 35 & $10.63(37.40)$ & $0-200$ & $0(0-0)$ & & \\
\hline \multirow{3}{*}{ II } & 1 & 35 & $21.29(42.83)$ & $0-150$ & $0(0-10)$ & \multirow{3}{*}{2.90} & \multirow{3}{*}{0.24} \\
\hline & 2 & 35 & $19.80(50.14)$ & $0-200$ & $0(0-0)$ & & \\
\hline & 3 & 35 & $09.0(27.26)$ & $0-126$ & $0(0-1)$ & & \\
\hline
\end{tabular}

$* \mathrm{p}<0.05$ statistically significant

Table 2: Comparison of E. faecalis colony count between the study groups at each time interval

\begin{tabular}{|c|c|c|c|c|c|c|c|}
\hline \multirow[t]{2}{*}{ Sample } & \multirow[t]{2}{*}{ Group } & \multirow[t]{2}{*}{ Number } & \multirow[t]{2}{*}{ Mean (SD) } & \multirow[t]{2}{*}{ Range } & \multirow{2}{*}{$\begin{array}{l}\text { Median } \\
\text { (Q1-Q3) }\end{array}$} & \multicolumn{2}{|c|}{ Mann Whitney U test } \\
\hline & & & & & & U statistic & p-value \\
\hline \multirow[t]{2}{*}{1} & I & 35 & $16.86(37.08)$ & $0-150$ & $0(0-10)$ & \multirow[t]{2}{*}{579.50} & \multirow[t]{2}{*}{0.63} \\
\hline & II & 35 & $21.29(42.83)$ & $0-150$ & $0(0-10)$ & & \\
\hline \multirow[t]{2}{*}{2} & $\mathrm{I}$ & 35 & $16.57(38.57)$ & $0-150$ & $0(0-0)$ & \multirow[t]{2}{*}{579.50} & \multirow[t]{2}{*}{0.81} \\
\hline & II & 35 & $19.80(50.14)$ & $0-200$ & $0(0-0)$ & & \\
\hline \multirow[t]{2}{*}{3} & $\mathrm{I}$ & 35 & $10.63(37.40)$ & $0-200$ & $0(0-0)$ & \multirow[t]{2}{*}{583.50} & \multirow[t]{2}{*}{0.64} \\
\hline & II & 35 & $09.0(27.26)$ & $0-126$ & $0(0-1)$ & & \\
\hline
\end{tabular}

Table 3: Comparison of $\boldsymbol{P}$. gingivalis colony count at different time intervals in each study groups.

\begin{tabular}{|c|c|c|c|c|c|c|c|c|c|c|}
\hline \multirow[t]{2}{*}{ Group } & \multirow[t]{2}{*}{ Sample } & \multirow[t]{2}{*}{ Number } & \multirow[t]{2}{*}{$\begin{array}{l}\text { Mean } \\
\text { (SD) }\end{array}$} & \multirow[t]{2}{*}{ Range } & \multirow[t]{2}{*}{$\begin{array}{l}\text { Median } \\
\text { (Q1-Q3) }\end{array}$} & \multicolumn{2}{|c|}{ Friedman test } & \multicolumn{3}{|c|}{$\begin{array}{c}\text { Wilcoxon sign rank test (p-value) } \\
\text { Comparing samples }\end{array}$} \\
\hline & & & & & & Chi square & p-value & $2-1$ & $3-1$ & $3-2$ \\
\hline \multirow[t]{3}{*}{ I } & 1 & 35 & $\begin{array}{c}32.60 \\
(53.96)\end{array}$ & $0-150$ & $0(0-100)$ & \multirow{3}{*}{6.24} & \multirow{3}{*}{$0.04 *$} & \multirow{3}{*}{0.25} & \multirow{3}{*}{$0.01 *$} & \multirow{3}{*}{$0.04 *$} \\
\hline & 2 & 35 & $\begin{array}{c}21.71 \\
(49.85)\end{array}$ & $0-200$ & $0(0-20)$ & & & & & \\
\hline & 3 & 35 & $\begin{array}{c}08.66 \\
(30.02)\end{array}$ & $0-150$ & $0(0-0)$ & & & & & \\
\hline \multirow[t]{3}{*}{ II } & 1 & 35 & $\begin{array}{c}54.86 \\
(76.86) \\
\end{array}$ & $0-250$ & $0(0-100)$ & \multirow{3}{*}{5.16} & \multirow{3}{*}{0.08} & & & \\
\hline & 2 & 35 & $\begin{array}{c}29.63 \\
(58.86)\end{array}$ & $0-200$ & $0(0-30)$ & & & & & \\
\hline & 3 & 35 & $\begin{array}{c}19.20 \\
(41.57)\end{array}$ & $0-150$ & $0(0-10)$ & & & & & \\
\hline
\end{tabular}

$* p<0.05$ statistically significant

Table 4: Comparison of $P$. gingivalis colony count between the study groups at each time interval

\begin{tabular}{|c|c|c|c|c|c|c|c|}
\hline \multirow[t]{2}{*}{ Sample } & \multirow[t]{2}{*}{ Group } & \multirow[t]{2}{*}{ Number } & \multirow[t]{2}{*}{ Mean (SD) } & \multirow[t]{2}{*}{ Range } & \multirow{2}{*}{$\begin{array}{l}\text { Median } \\
\text { (Q1-Q3) }\end{array}$} & \multicolumn{2}{|c|}{ Mann Whitney U test } \\
\hline & & & & & & U statistic & p-value \\
\hline \multirow[t]{2}{*}{1} & I & 35 & $32.60(53.96)$ & $0-150$ & $0(0-100)$ & \multirow[t]{2}{*}{546.00} & \multirow[t]{2}{*}{0.38} \\
\hline & II & 35 & $54.86(76.86)$ & $0-250$ & $0(0-100)$ & & \\
\hline \multirow[t]{2}{*}{2} & I & 35 & $21.71(49.85)$ & $0-200$ & $0(0-20)$ & \multirow[t]{2}{*}{576.50} & \multirow[t]{2}{*}{0.62} \\
\hline & II & 35 & $29.63(58.86)$ & $0-200$ & $0(0-30)$ & & \\
\hline \multirow[t]{2}{*}{3} & I & 35 & $08.66(30.02)$ & $0-150$ & $0(0-0)$ & \multirow[t]{2}{*}{506.50} & \multirow[t]{2}{*}{0.11} \\
\hline & II & 35 & $19.20(41.57)$ & $0-150$ & $0(0-10)$ & & \\
\hline
\end{tabular}

${ }^{*} p<0.05$ statistically significant

\section{Results}

In the present randomized in vivo split mouth study, no statistically significant differences were found between the groups. Statistical evaluation showed decreased colony numbers in samples from pre-irrigation, post-irrigation and post-48 hours for each organism in groups I and II. A statistically vital difference was noted in the reduction of $P$. gingivalis colonies in the group I from preirrigation to post-48 hours of irrigation $(\mathrm{p}<0.05)$
(Table 3). No significant disparity was noted between group I and group II (Tables $2 \& 4$ ).

\section{Discussion}

Bacterial synergism in the infected root canals may cause resistance to antimicrobial irrigating agents ${ }^{7}$. It is also clear that the gold standard irrigant $\mathrm{NaOCl}$ has toxic side effects $^{3,4}$. Thus an alternative irrigating agent is the need of the hour in paediatric dentistry $^{6}$. Studies show that microbes in permanent root canals are similar to that of primary 
teeth $^{5}$. P. gingivalis and the resistant E. faecalis were among the most frequent organisms in deciduous root canal infection ${ }^{1,8}$. Laboratory studies have been done on planktonic cultures of bacterial strains, but they least resemble the biofilm formation on the wall of infected root canals ${ }^{9}$. These facts encouraged us to go ahead with our study using an in vivo technique.

In our study, samples were obtained from the single largest necrotic root canal to narrow down the microbial growth evaluation to a single ecological condition $^{10,11}$. To determine the antimicrobial effectiveness of any remaining irrigant in the canals after obtaining initial samples, the pulp chambers were sealed with cotton and Glass Ionomer cement for next 48 hours. The effect on the bacteria inaccessible to the irrigant during the initial irrigation could be evaluated ${ }^{12}$. E. faecalis and $P$. gingivalis were found to be surviving post irrigation according to Gomes et al. ${ }^{13}$ Also, Oncag et $a l^{5}$ suggest that $E$. faecalis count reduced more after 48 hours, thus backing the idea of collecting samples two days after the day of initial irrigation. Culturing makes it possible to quantify all major bacteria in samples and broad range prototype. Thus in our study it was decided to choose the culturing technique to determine and detect the presence of E. faecalis and $P$. gingivalis $^{14}$. Root canal samples were transported for culturing in a reduced transport medium which reduced oxygen and prevented superoxide radicals which would kill anaerobic bacteria included in our study, especially $P$. gingivalis which is an anaerobic strain, unlike $E$. faecalis which is a facultative anaerobe ${ }^{8}$.

E. faecalis was selected as an experimental species as it was an easily cultivable, non-fastidious organism associated with resistant cases of apical infection after treatment ${ }^{14}$. Antibacterial effects of new drugs and irrigants opposing E. faecalis are of interest as the organism is often isolated from treated root canals ${ }^{4,9}$. Black pigmented anaerobic rods like $P$. gingivalis have been associated with the signs of acute peri-radicular inflammation. Their characteristics create a disorder in the host immune response against it, thus potentiating tissue destruction ${ }^{11}$. Their resistance against the biomechanical irrigation and instrumentation may be the key reason they are found in treated canals, keeping an ability to reinstate the infection. $P$. gingivalis has been found in deciduous root canals which is similar to studies on adults, synergistically aiding in infection ${ }^{7}$. E. faecalis and $P$. gingivalis species were isolated often from toddlers and preschoolers with necrotic pulp, but could not be explained with ease as there is a scarcity of studies highlighting associations in deciduous teeth ${ }^{7}$. Bacterial associations between black pigmented bacteria and Enterococcus species was noted ${ }^{15}$. Thus we selected these two strains in our study.

$\mathrm{NaOCl}$ in higher concentrations has shown weakening consequences on the teeth ${ }^{16}$. A compromise in the dentinal micro hardness and modulus of elasticity was seen more when exposed to higher concentration of $5.25 \% \mathrm{NaOCl}$ than a lesser concentration ${ }^{17}$. Concentrations close to $3 \%$ was found to be effective against, smear layer, predentin, debris, remaining pulp tissue, along with important organisms like E. faecalis, and $P$. gingivalis $^{18,19,20}$. Hence a low effective concentration of $3 \%^{21,22}$ was chosen as control. Strong acid electrolyzed water (SAEW) or electrochemically activated water or oxidative potential water has been slowly finding its role in this arena. The idea of electrolyzed water found its origin in Russia, where it was used for regenerating and decontaminating water. Initially, it was used in sterilizing instrument in medical institutes followed by areas of agriculture or livestock management ${ }^{23}$. It is hazardous for bacteria but safe to the human tissue.

Resistance to a thousand times is noticed in naturally formed biofilms than broth grown counterparts. E. faecalis biofilms have been detected in infected root canals ${ }^{16}$. According to Marias JT et $a l^{12}$ electrolysed water is efficient against biofilms formed in the dental unit waterline. Anolyte solution has been effective against $E$. faecalis according to Cheng X, et $a l^{3}$ and $P$. gingivalis according to Lee $\mathrm{SH}$. et $a l^{14}$. Thus we used electrolysed water as an irrigant against $E$. faecalis and $P$. gingivalis in the experimental group. Our study exhibits that $\mathrm{NaOCl}$ and SAEW are efficient against $E$. faecalis and $P$. gingivalis counts in an infected deciduous tooth. Bacterial colony count was highest from the pre-irrigation sample, it reduced in the post-irrigation sample and the least colony count was found from the samples taken after 48 hours. This reflects the effectiveness of $\mathrm{NaOCl}$ and SAEW against the aforementioned organisms in a positive manner. SAEW is able to have a degrading effect on the existence of $E$. faecalis and $P$. gingivalis. On intergroup comparison no statistically significant difference was noted among the groups. This is because both these irrigants are exerting similar effectiveness in lowering the bacterial count from the first preirrigation sample to the last sample taken after 48 hours.

When $P$. gingivalis colony counts were compared, a declining trend was noticed in the $\mathrm{NaOCl}$ as well as SAEW group. The comparison of the colonies in the $\mathrm{NaOCl}$ group showed statistically significant difference. A noteworthy reduction was noted in $P$. gingivalis samples taken before and after irrigation 
when compared to the post 48 hour sample in the $\mathrm{NaOCl}$ group. Dhariwal et $a l^{21}$ mentions in his culture study that obligatory anaerobes like $P$. gingivalis are more sensitive to $\mathrm{NaOCl}$ than facultative anaerobes like E. faecalis. Stojanovic et $a l^{24}$ through his molecular study states that such gram negative organisms are eliminated with low concentration of $\mathrm{NaOCl}$. Sakamoto et $a l^{25}$ through their culture study shows that $P$. gingivalis failed to thrive well after detecting positive growth in the first samples were taken.

Similar to our results, Cheng $\mathrm{X}$, et $a l^{3}$, Zan $\mathrm{R}$, et $a l^{26}$ and Gomi $\mathrm{K}$, et $a l^{27}$ found SAEW to be equally effective as $\mathrm{NaOCl}$ against E. faecalis and had a better smell than $\mathrm{NaOCl}$. On the contrary, MenaMendivil et a ${ }^{28}$ through their in vitro study showed that $\mathrm{NaOCl}$ gave better results than electrolyzed water against $E$. faecalis and $P$. gingivalis. Our results are also similar to studies by Lee $\mathrm{SH}$, et $a l^{12}$, Chen CJ, et $a l^{29}$, Mena-Mendivil ED, et $a l^{28}$, and Kim $\mathrm{SB}^{30}$ which show that electrolysed water is effective against $P$. gingivalis. In our study, $E$. faecalis was seen in $45.7 \%$ of the cases while $P$. gingivalis was seen in $54.3 \%$ of cases of primary molars. E. faecalis was found by Chandwani $\mathrm{M}$, et $a l^{31}$ in $30 \%$, Cogulu $\mathrm{D}$, et $a l^{1}$ in $16 \%$, Oncag $\mathrm{O}$, et al in $63 \%{ }^{32}$ and Siqueira JF Jr, et $a l^{33}$ in $7.5 \%$ in primary root canals. $P$. gingivalis was detected by Cogulu D, et $a l^{1}$ in $16 \%$, Gomes GB, et al in $100 \%$, Yang QB, et $a l^{34}$ in $13.9 \%$ and Fabris As, et $a l^{7}$ in $49 \%$ in the primary root canal. Still, a significant amount of bacteria prevailed following irrigation. A rise in resistance against antimicrobial irrigants used in paediatric dental practice seems to enhance due to the synergism of $E$. faecalis and $P$. gingivalis strains ${ }^{7}$. Hence, the biocompatible and safe SAEW seems promising as an ideal irrigant for deciduous root canals, especially for pediatric dental patients.

The strength in this study lies in the fact that this is an in vivo study which took bacterial samples from the oral conditions. Through this study, a safer antibacterial alternative for root canal irrigation was observed in SAEW, especially for paediatric dental practice. The limitations of the study are that it had a small sample size and that patients were not evaluated with follow up after completion of pulpectomy. Since our study is among the very few studies done on primary molars using SAEW, more research with a larger sample and follow up is needed before coming to a definite conclusion.

\section{Conclusions}

1. Sodium hypochlorite is an efficient irrigating agent against $E$. faecalis and $P$. gingivalis in infected deciduous molar root canals. However it showed better declining effect on $P$. gingivalis colony count.

2. Strong acid electrolysed water is an efficient irrigating agent against $E$. faecalis and $P$. gingivalis in deciduous molar root canals.

3. On comparison of the two irrigants for their efficacy against $E$. faecalis and $P$. gingivalis, results showed both to be equally effective.

\section{References}

1. Cogulu D, Uzel A, Oncag O, Eronat C. PCR-based identification of selected pathogens associated with endodontic infections in deciduous and permanent teeth. Oral Surgery, Oral Medicine, Oral Pathology, Oral Radiology and Endodondics 2008; 106(3): 443-9. https://doi.org/10.1016/j.tripleo.2008.03.0 04

PMid: 18547832

2. Gomes GB, Sarkis-Onofre R, Bonow ML, Etges A, Jacinto RC. An investigation of the presence of specific anaerobic species in necrotic primary teeth. Brazilian Oral Research 2013; 27(2): 149-55. https://doi.org/10.1590/S18068324201300 0100020

PMid: 23538426

3. Cheng X, Tian Y, Zhao C, Qu T, Ma C, Liu X, et al. Bactericidal effect of strong acid electrolysed water against flow Enterococcus faecalis biofilms. Journal of Endodontics 2016; 42(7): 1120 -5. https://doi.org/10.1016/j.joen.2016.04.009 PMid: 27208991

4. Ismail S., Adyanthaya A., Sreelakshmi N. Intracanal irrigants in pediatric endodontics: A review. International Journal of Applied Dental Sciences 2017; 3(4): 246-51.

5. Onçağ $\mathrm{O}$, Hoşgör $\mathrm{M}$, Hilmioğlu $\mathrm{S}$, Zekioğlu O, Eronat C, Burhanoğlu D. Comparison of antibacterial and toxic effects of various root canal irrigants. International Endodontic Journal 2003; 36(6): 423-32.

https://doi.org/10.1046/j.13652591.2003.0 0673.x

PMid: 12801290

6. Tirali RE, Bodur $\mathrm{H}$, Ece $\mathrm{G}$. In vitro antimicrobial activity of sodium 
hypochlorite, chlorhexidine gluconate and octenidine dihydrochloride in elimination of microorganisms within dentinal tubules of primary and permanent teeth. Medicina Oral, Patologia Oral, Cirugia

Bucal 2012; 17(3): e517-22.

https://doi.org/10.4317/medoral.17566

PMid: 22143724 PMCid: PMC3476099

7. Fabris AS, Nakano V, Avila-Campos MJ. Bacteriological analysis of necrotic pulp and fistulae in primary teeth. Journal of Applied Oral Science 2014; 22(2):118-24. https://doi.org/10.1590/167877572013035 8

PMid: 24676582 PMCid: PMC3956403

8. Farhin K, Viral PM, Thejokrishna P, Sajjad M. Reduction in bacterial loading using MTAD as an irrigant in pulpectomized primary teeth. Journal of Clinical Pediatric Dentistry 2015; 39(2): 100-4.

https://doi.org/10.17796/jcpd.39.2.r12353

27331r26hn

PMid: 25951307

9. Dunavant TR, Regan JD, Glickman GN, Solomon ES, Honeyman AL. Comparative evaluation of endodontic irrigants against Enterococcus faecalis biofilms. Journal of Endodontics 2006; 32(6): 527-31. https://doi.org/10.1016/j.joen.2005.09.001 PMid: 16728243

10. Rajaram A, Kotrashetti VS, Somannavar $\mathrm{PD}$, Ingalagi $\mathrm{P}$, Bhat K. Culture-based identification of pigmented Porphyromonas and Prevotella species in primary endodontic infections. Journal of Dental Research, Dental Clinics, Dental Prospects 2016; 10(3): 136-41. https://doi.org/10.15171/joddd.2016.022

PMid: 27651878 PMCid: PMC5025213

11. Pabla T, Gulati MS, Mohan U. Evaluation of antimicrobial efficacy of various root canal filling materials for primary teeth. Journal of Indian Society of Pedodontics and Preventive Dentistry 1997; 15(4): 134-40.

12. Marais JT, Brözel VS. Electro-chemically activated water in dental unit water lines. British Dental Journal 1999; 187(3): 1548.

https://doi.org/10.1038/sj.bdj.4800228

PMid: 10481367
13. Gomes BPFA, Lilley JD, Drucker DB. Variations in the susceptibilities of components of the endodontic microflora to biomechanical procedures. International Endodontic Journal 1996; 29(4): 235-41.

https://doi.org/10.1111/j.13652591.1996.t

b01375.x

PMid: 9206439

14. Lee SH, Choi BK. Antibacterial effect of electrolysed water on oral bacteria. Journal of Microbiology 2006; 44(4): 41722.

15. Sundqvist G, Johansson E, Sjögren U. Prevalence of black-pigmented bacteroides species in root canal infections. Journal of Endodontics 1989; 15(1): 13-9.

https://doi.org/10.1016/S00992399(89)80 092-5

16. Pazelli LC, Freitas AC, Ito IY, SouzaGugelmin MC, Medeiros AS, NelsonFilho P. Prevalence of microorganisms in root canals of human deciduous teeth with necrotic pulp and chronic periapical lesions. Pesqui Odontol Bras. 2003; 17(4): 367-71.

https://doi.org/10.1590/S15177491200300 0400013

PMid: 15107921

17. Sim TP, Knowles J, Ng YL, Shelton J, Gulabivala K. Effect of sodium hypochlorite irrigant concentration on strain in teeth. International Endodontic Journal 2001; 34(2): 120-32.

https://doi.org/10.1046/j.13652591.2001.0 0357.x

PMid: 11307260

18. Gordon TM, Damato D, Christner P. Solvent effect of various dilutions of sodium hypochlorite on vital and necrotic tissue. Journal of Endodontics 1981; 7(10): 4-9.

https://doi.org/10.1016/S00992399(81)80 308-1

19. Mohammadi Z. Sodium hypochlorite in endodontics: an update review. International Dental Journal 2008; 58(6): 329-41.

https://doi.org/10.1111/j.1875595X.2008.t b00354.x

PMid: 19145794 
20. Baumgartner JC, Cuenin PR. Efficacy of several concentrations of sodium hypochlorite for root canal irrigation. Journal of Endodontics 1992; 18(12): 605-12.

https://doi.org/10.1016/S00992399(06)81 $331-2$

21. Dhariwal NS, Hugar SM, Harakuni S, Sogi S, Assudani HG, Mistry LN. A comparative evaluation of antibacterial effectiveness of sodium hypochlorite, Curcuma Longa, And Camellia Sinensis as irrigating solutions on isolated anaerobic bacteria from infected primary teeth. Journal of Indian Society of Pedodontics and Preventive Dentistry 2016; 34(2): 165-71.

https://doi.org/10.4103/0970-4388.180447 PMid: 27080968

22. Karale R, Thakore A, Shetty V. An evaluation of antibacterial efficacy of 3\% sodium hypochlorite, high-frequency alternating current and 2\% chlorhexidine on Enterococcus faecalis: An in vitro study. Journal of Conservative Dentistry 2011; 14(1): 2-5.

https://doi.org/10.4103/0972-0707.80721

PMid: 21691496 PMCid: PMC3099107

23. Hricova D, Stephan R, Zweifel C. Electrolysed water and its application in the food industry. Journal of Food Protection 2008; 71(9): 1934-47. https://doi.org/10.4315/0362-028X71.9 .1934

PMid: 18810883

24. Stojanović N, Krunić J, Popović B, Stojičić S, Zivković S. Prevalence of Enterococcus Faecalis and Porphyromonas Gingivalis in infected root canals and their susceptibility to endodontic treatment procedures: A molecular study. Srp Arh Celok Lek. 2014; 142(9-10): 535-41.

https://doi.org/10.2298/SARH1410535S

PMid: 25518530

25. Sakamoto M, Siqueira JF Jr, Rôças IN, Benno Y. Bacterial reduction and persistence after endodontic treatment procedures. Oral Microbiology and Immunology 2007; 22(1): 19-23. https://doi.org/10.1111/j.1399302X.2007. 00315.x

PMid: 17241166
26. Zan R, Alacam T, Hubbezoglu I, Tunc T, Sumer Z, Alici O. Antibacterial efficacy of super-oxidized water on Enterococcus faecalis biofilms in root canal. Jundishapur Journal of Microbiology 2016; 9(9): e30000.

https://doi.org/10.5812/jjm.30000

PMid: 27800142 PMCid: PMC5086080

27. Gomi K, Makino T, Suzuki S, Hasegawa M, Maeda N, Arai T. Microbicidal and cytotoxic effects of functional water in vitro. Quintessence International 2010; 41(9): e166-72.

28. Mena-Mendivil ED, Flores-Treviño JJ, Rodríguez-Delgado I, de La Garza-Ramos MA, Torre-Martinez HH, MartinusGonzález GI. Antimicrobial effect of Microdacyn 60, OxOral, and sodium hypochlorite $5.25 \%$ in anaerobic bacteria. Journal of Pharmacognosy and Phytotherapy 2013; 5(10): 178-82.

29. Chen CJ, Chen CC, Ding SJ. Effectiveness of hypochlorous acid to reduce the biofilms on titanium alloy surfaces in vitro. International Journal of Molecular Sciences 2016; 17(7): e1161. https://doi.org/10.3390/ijms17071161 PMid: 27447617 PMCid: PMC4964533

30. Kim SB. Development of a mouthwash alternative using a low-level hypochlorous acid solution with macroporous platinum electrodes and its application to oral health. International Journal of Clinical and Experimental Medicine 2016; 9(11): 21304-11.

31. Chandwani M, Chandak S. Assessment of facultative anaerobes from the root canals of deciduous molars: An in vivo study. Journal of Dental Research, Dental Clinics, Dental Prospects 2017; 11(2): 96100.

https://doi.org/10.15171/joddd.2017.018

PMid: 28748050 PMCid: PMC5520000

32. Onçag O, Cogulu D, Uzel A. Efficacy of various intracanal medicaments against Enterococcus Faecalis in primary teeth: An in vivo study. Journal of Clinical Pediatric Dentistry 2006; 30(3): 233-7. https://doi.org/10.17796/jcpd.30.3.r773j61 674lw0268 PMid: 16683672 
33. Siqueira JF Jr, Rôças IN, Souto R, De Uzeda M, Colombo AP. Actinomyces Species, Streptococci and Enterococcus Faecalis in primary root canal Infections. Journal of Endodontics 2002; 28(3):16872. https://doi.org/10.1097/000047702002030 00-00006

PMid: 12017173

34. Yang QB, Fan LN, Shi Q. Polymerase chain reaction-denaturing gradient $\mathrm{Gel}$
Electrophoresis, Cloning, and Sequence analysis of bacteria associated with acute periapical abscesses in children. Journal of Endodontics 2010; 36(2): 218-23.

https://doi.org/10.1016/j.joen.2009.11.001 PMid: 20113778 